\title{
U-Pb SHRIMP and Sm-Nd geochronology of the Silvânia Volcanics and Jurubatuba Granite: juvenile Paleoproterozoic crust in the basement of the Neoproterozoic Brasilia Belt, Goiás, central Brazil
}

\author{
DANIELLE P. FISCHEL ${ }^{1}$, MÁRCIO M. PIMENTEL ${ }^{1}$, REINHARDT A. FUCK ${ }^{1}$ \\ and RICHARD ARMSTRONG ${ }^{2}$ \\ ${ }^{1}$ Instituto de Geociências, Universidade de Brasília, Brasília-DF, 70910-900, Brazil \\ ${ }^{2}$ Research School of Earth Sciences, The Australian National University, Canberra, ACT 0200, Australia \\ Manuscript received on November 23, 2000; accepted for publication on May 30, 2001; \\ contributed by R. A. FucK AND M. M. Pimentel
}

\begin{abstract}
U-Pb SHRIMP and Sm-Nd isotopic ages were determined for felsic metavolcanic rocks from the Silvânia Sequence and Jurubatuba Granite in the central part of the Brasília Belt. Zircon grains from a metavolcanic sample yielded $2115 \pm 23 \mathrm{Ma}$ and from the granite yielded $2089 \pm 14 \mathrm{Ma}$, interpreted as crystallization ages of these rocks.

Six metavolcanic samples of the Silvânia Sequence yielded a six-point whole-rock Sm-Nd isochron indicating a crystallization age of $2262 \pm 110 \mathrm{Ma}$ and positive $\varepsilon_{\mathrm{Nd}}(\mathrm{T})=+3.0$ interpreted as a juvenile magmatic event.

$\mathrm{Nd}$ isotopic analyses on samples from the Jurubatuba Granite have Paleoproterozoic $\mathrm{T}_{\mathrm{DM}}$ model ages between 2.30 and $2.42 \mathrm{Ga}$ and $\varepsilon_{\mathrm{Nd}}(\mathrm{T})$ values vary between -0.22 and -0.58 . The oldest $\mathrm{T}_{\mathrm{DM}}$ value refers to a sedimentary xenolith in the granite. These results suggest crystallization ages of Silvânia volcanics and Jurubatuba Granite are the first evidence of a ca. 2.14-2.08 juvenile magmatic event in the basement of the central part of the Brasília Belt that implies the presence of arc/suture hidden in reworked basement of the Brasília Belt.
\end{abstract}

Key words: U-Pb SHRIMP, Sm-Nd isotopic data, Brasília Belt, basement rocks.

\section{INTRODUCTION}

The Brasília Belt is a large Neoproterozoic orogen formed along the western margin of the São Francisco/Congo Craton in central Brazil. It comprises: (i) a thick Meso-Neoproterozoic metasedimentary/ sedimentary pile with eastward tectonic vergence; (ii) a large Neoproterozoic juvenile arc in the west (Goiás Magmatic Arc); and (iii) a micro-continent (or exotic sialic terrain) formed by Archean rock units (the Crixás-Goiás granite-greenstones) and as-

Correspondence to: Danielle P. Fischel / Reinhardt A. Fuck E-mail: piuzana@unb.br/rfuck@unb.br sociated Proterozoic formations (Almeida et al. 1981, Fuck et al. 1993, 1994, Pimentel et al. 2000a, b) (Figure 1) .

The sialic basement on which the Brasília Belt sediments were deposited is poorly understood, despite being well exposed in some areas of Goiás and Tocantins states (Figure 1). Gneiss and volcanosedimentary units form most of this basement. Early studies have suggested that these rock units are dominantly Archean (Danni et al. 1982, Marini et al.1984). However, recent Sm-Nd isotopic studies have indicated that most of them are Paleoprotero- 
zoic (Pimentel et al. 1999a, 2000b, Sato 1998).

In central Goiás, a large part of the Brasília Belt is underlain by high-grade metamorphic rocks known as the Anápolis-Itauçu Complex, together with surrounding greenschist to amphibolite facies Meso- to Neoproterozoic cover metasediments of the Araxá Group, these rocks represent the main constituent of the internal zone of the Neoproterozoic Brasília Belt (Fuck et al. 1994, Pimentel et al. 2000b) (Figures 1 and 2). There are also volcanosedimentary associations and granites. One of the supracrustal associations is known as Silvânia Sequence (Valente 1986); together with the Jurubatuba Granite, it is located between the Araxá Group, and the easternmost part of the Anápolis-Itauçu Complex (Figure 2).

Several high grade rock types have been recorded within the Anápolis-Itauçu Complex, the most extensive of which are felsic granulites, sillimanite-garnet gneiss, hypersthene bearing mafic-ultramafic granulites, and many granite intrusions.

In this study we investigate the age and isotopic characteristics of the Silvânia Sequence and the Jurubatuba Granite. We report U-Pb SHRIMP age determinations and $\mathrm{Sm}-\mathrm{Nd}$ isotopic studies of these rock units in order to understand their nature, timing of crystallization and mantle extraction aiming their tectonic significance within the framework of the Brasília Belt (Figures 1 and 2).

\section{NEOPROTEROZOIC BRASÍLIA BELT}

The Brasília Belt in central Brazil constitutes the central/eastern part of the Tocantins province, representing a roughly $\mathrm{N}-\mathrm{S}$ belt extending for more than $1000 \mathrm{~km}$ along the western margin of the São Francisco/Congo Craton.

The Tocantins Province resulted from collision of three major continental blocks at the end of the Neoproterozoic: the Amazon Craton, to the west, the São Francisco/Congo Craton, to the east, and the Paranapanema block, to the south, presently covered by Phanerozoic rocks of the Paraná Basin.
The westernmost part of the Brasília Belt consists of a Neoproterozoic juvenile arc (Goiás Magmatic Arc) formed by arc type volcano-sedimentary rocks and tonalite/granodiorite gneisses with ages ranging from ca. 930 to $640 \mathrm{Ma}$ ago (Pimentel et al. 1991, 1997, Pimentel and Fuck 1992).

The central part of the Brasília Belt consists of the Goiás Massif, represented by: (i) Archean greenstone belts and TTG orthogneisses; (ii) Paleoproterozoic orthogneisses largely covered by younger supracrustals; (iii) Paleo- Mesoproterozoic maficultramafic layered complexes of Barro Alto, Niquelândia, and Canabrava and associated volcano-sedimentary sequences (Fuck et al. 1994, Pimentel et al. 2000b).

East of the Goiás Massif the easternmost part of the Brasília Belt is known as the external zone (Figure 1). This is largely comprised of Neoproterozoic metasedimentary units in which deformation and metamorphism decrease eastwards towards the São Francisco Craton. Northwards, these Neoproterozoic units (see Dardenne 2000 for a comprehensive review) lie unconformably over Paleoproterozoic basement units containing minor Archean contribution (Correia et al. 1997, Sato 1998, Pimentel et al. 2000a, Cruz et al. 2000). It has been suggested that these rocks may represent the western extension of the São Francisco Craton.

To the southeast of Goiás Massif is the metamorphic complex of the internal zone of the Brasília Belt. This part of the belt comprises mainly the Araxá Group metasediments including an ophiolite mélange (Drake Jr. 1980, Strieder and Nilson 1992) and intensively deformed intrusive granites. The internal zone also includes the high grade rocks of the Anápolis-Itauçu Complex. The age and tectonic significance of the Anápolis-Itauçu Complex is still a matter of debate. It has been traditionally interpreted as Archean basement within the Brasília Belt (Danni et al. 1982, Marini et al. 1984, Wolff 1991, Lacerda Filho and Oliveira 1995, Winge 1995). However, recent isotopic data have challenged this model (Fischel et al. 1998, 1999, Pimentel et al. 1999a). $\mathrm{T}_{\mathrm{DM}}$ model ages of granulites and metasediments 


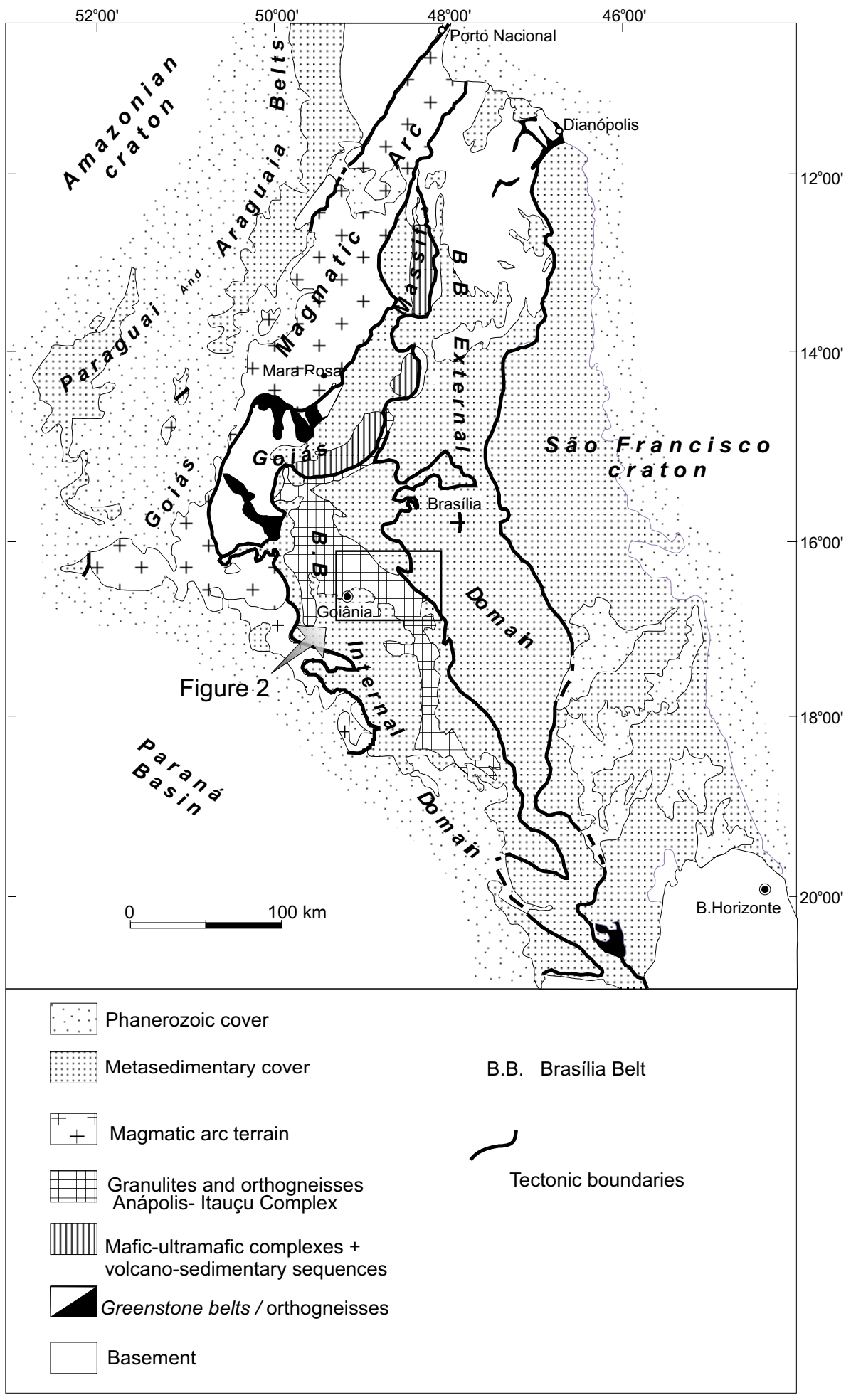

Fig. 1 - Geological sketch of the Brasília Belt. Modified after Fuck et al. (1994). 


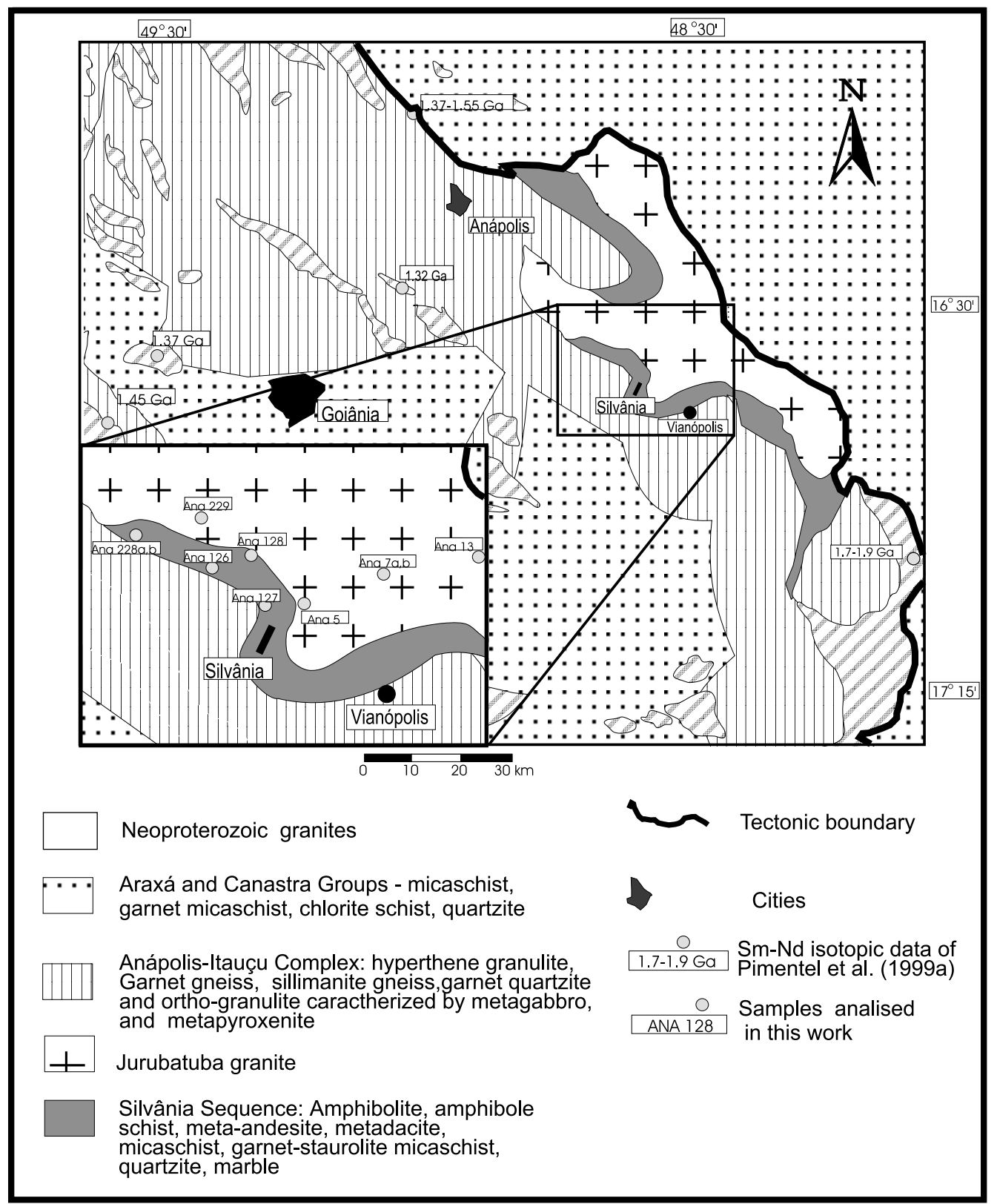

Fig. 2 - Geological sketch of the study area. Modified after Araújo (1994) and Lacerda Filho and Oliveira (1995).

fall within the interval between 1.9 and $1.2 \mathrm{Ga}$. These model ages are interpreted as the approximate upper limit for the age of the protoliths. The similarity of Nd isotopic composition of felsic granulites and metapelites of the Araxá Group led to the suggestion that at least some of the felsic granulites could represent high grade equivalents of the Araxá Group metasediments (Pimentel et al. 1999a).

Metasediments of the Araxá Group surrounding the Anápolis-Itauçu Complex (Figures 1 and 2) 
show bimodal distribution of $\mathrm{T}_{\mathrm{DM}}$ model ages. A group of samples displays $\mathrm{T}_{\mathrm{DM}}$ values between 1.8 and $2.3 \mathrm{Ga}$ and another group shows younger model ages, between ca. 1.0 and $1.3 \mathrm{Ga}$ (Pimentel et al. 1999b, 2000b, Fischel et al. 1999).

Granite intrusions in the Anápolis-Itauçu Complex were metamorphosed under high grade conditions at ca. $630 \mathrm{Ma}$ ago (Sm-Nd whole rock-garnet isochron, Fischel et al. 1998). The same age was established with U-Pb SHRIMP data on metamorphic zircons from the Hinterlândia quarry granulite (Tassinari et al. 1999).

To the east of the high grade terrains the sediments of the Araxá Group were overthrusted on top of the thick metasedimentary/sedimentary pile of the external zone of the Brasília Belt. These rocks display tectonic vergence to the east, and constitute the Neoproterozoic Paranoá, Canastra, Ibiá and Vazante groups (Fuck et al. 1993, 1994, Dardenne 2000) (Figure 1). Nd isotopic composition of the Paranoá and Canastra groups indicate that these sediments were derived from a Paleoproterozoic source, probably from the São Francisco continent (Pimentel et al. 2000b). However, several rock samples of the Araxá and Ibiá groups have very young model ages, suggesting contribution from Neoprotezoic juvenile source areas, such as the Goiás Magmatic Arc.

\section{GENERAL GEOLOGY}

\section{The Anápolis-Itauçu Complex}

The Anápolis-Itauçu Complex consists of a NW-SE elongated zone (approximately $250 \mathrm{~km}$ long, $70 \mathrm{~km}$ wide) within the internal domain of the Brasília Belt (Figure 1). It is a complex association of highgrade rocks including mafic-ultramafic intrusions, charnockites, enderbites, granites, as well as Al-rich granulites of sedimentary origin, associated with marbles and quartzites. Part of the para-granulites are believed to represent the products of high grade metamorphism of pelites and graywackes (Wolff 1991, Araújo 1994, Winge 1995). The AnápolisItauçu Complex is separated by low and high angle shear zones from the Araxá sediments which com- prise a turbiditic sequence of paragneiss, micaschist, quartzite, carbonate-bearing schists with minor carbonaceous schists, metacherts (Lacerda Filho and Oliveira 1995), and small alpine-type mafic-ultramafic bodies tectonically interlayered with the sedimentary rocks (Drake Jr 1980, Strieder and Nilson 1992). A number of peraluminous granite bodies is exposed within the Anápolis-Itauçu Complex (Figure 2). Some are strongly deformed and metamorphosed under high-grade conditions and are now represented by sillimanite and garnet-bearing rocks.

\section{The Silvânia Sequence And the Jurubatuba Granite}

The volcano-sedimentary Silvânia Sequence (Valente 1986) forms a ca. $70 \mathrm{~km}$ long NW-SE strip limited to the southwest by felsic granulites of the Anápolis-Itauçu Complex and to the northeast by the Jurubatuba Granite. The Silvânia Sequence and Jurubatuba Granite are strongly deformed, displaying a NW-SE foliation, typical of the central and southern parts of the Brasília Belt.

The Silvânia Sequence comprises two units: (i) a metavolcanic unit of garnet-rich amphibolite, metabasalt, meta-andesite, and felsic metavolcanic rocks and (ii) a metasedimentary unit of quartzite, garnet quartzite, micaschist, and garnet micaschist. Lithogeochemical data indicate tholeiitic to calcalkaline signatures for the metavolcanic unit (Oliveira 1994, Freitas and Kuyumjian 1995).

The $65 \mathrm{~km}$ long, NW-SE trending Jurubatuba granite crops out to the northeast of the Silvânia Sequence and the contact is of tectonic nature striking N50W and dipping $70^{\circ}$ to NE. The northern margin of the granite is charactherized by a faulted contact with metasediments of the Araxá Group. The granite body is homogeneous and is composed essentially of a white to pink, foliated biotite granite with hypidiomorphic K-feldspar, plagioclase, quartz, and reddish biotite in thin section. Xenoliths of mafic and metasedimentary rocks (quartz-garnetbiotite schist) are common. 


\section{U-Pb SHRIMP AND Sm-Nd RESULTS}

\section{Analytical Procedures}

\section{$U-P b$ SHRIMP}

$20 \mathrm{~kg}$ of each sample ANA 128 (felsic volcanic rock from the Silvânia Sequence) and ANA 5 (Jurubatuba granite) were collected (Figure 2). Rock samples were initially crushed to $\mathrm{cm}$-sized fragments using a jaw crusher. The fragments were then ground, in small batches, in a tungsten carbide disk.

Each sample was sieved and heavy mineral concentrates were obtained using a DENSITEST ${ }^{\circledR}$ table. The concentrates were then passed through a Frantz isodynamic magnetic separator to obtain a pure zircon fraction. At least 100 representative zircons were hand-picked from this fraction under a binocular microscope, mounted in a one inch diameter epoxy disk with standard zircon crystals SL13 + AS3 and sectioned approximately in half. The mount surface was then polished to expose the grain interiors. The mount was then photographed at X150 magnification in reflected and transmitted light and CL images were obtained in order to reveal internal structures of the zircons.

Ion microprobe analyses were carried out using SHRIMP at the Research School of Earth Sciences, Australian National University, Canberra, Australia. SHRIMP analytical methods and data treatment follow those described by Stern (1997), Williams and Meyer (1998).

Uncertainties reported in tables and figures are given at $1 \sigma$ level, and final ages are quoted at $95 \%$ confidence level. Concordia diagrams were calculated and yielded using Isoplot (Ludwig 1999).

\section{Sm-Nd}

Sm-Nd isotopic analyses followed the method described by Gioia and Pimentel (2000) and were carried out at the Geochronology Laboratory of the University of Brasília. Whole rock powders (ca. $50 \mathrm{mg}$ ) were mixed with ${ }^{149} \mathrm{Sm}^{-150}{ }^{15 d}$ spike solution and dissolved in Savillex capsules. Sm and $\mathrm{Nd}$ extraction of whole-rock samples followed con- ventional cation exchange techniques, using teflon columns containing LN-Spec resin (HDEHP - diethylhexil phosphoric acid supported on PTFE powder). Sm and Nd samples were loaded on Re evaporation filaments of double filament assemblies and the isotopic measurements were carried out on a multi-collector Finnigan MAT 262 mass spectrometer in static mode. Uncertainties for $\mathrm{Sm} / \mathrm{Nd}$ and ${ }^{143} \mathrm{Nd} /{ }^{144} \mathrm{Nd}$ ratios are better than $\pm 0,2 \%(2 \sigma)$ and $\pm 0.003 \%(2 \sigma)$ respectively, based on repeated analyses of international rock standards BHVO-1 and BCR-1. ${ }^{143} \mathrm{Nd} /{ }^{144} \mathrm{Nd}$ ratios were normalized to ${ }^{146} \mathrm{Nd} /{ }^{144} \mathrm{Nd}$ of 0.7219 and the decay constant $(\lambda)$ used was $6.54 \times 10^{-12} . \mathrm{T}_{\mathrm{DM}}$ values were calculated using De Paolo's (1981) model. Isochron ages were calculated using Isoplot (Ludwig 1999).

\section{SilvâNIa SEquence}

Sample ANA 128 contains pink elongate zircon crystals. Cathodeluminescence (CL) images of zircon grains typically show cores with fine magmatic zoning, surrounded by rims with irregular, patchy zoning (Figure 3A).

Fourteen spots in ten zircons were analysed (Table I). Ten analyses yield a nearly concordant age of $2115 \pm 23 \mathrm{Ma}$ (Figure 4). One rim (analysis 3.2) yielded an age of $524 \pm 83$ Ma for metamorphic overgrowth (Figure 4).

One felsic (ANA 128) and five mafic (ANA 126, 127a, 127b, 228a, 228b) metavolcanic rocks samples of the Silvânia Sequence yield a six-point whole-rock isochron (Table II) with a regression line $(\mathrm{MSWD}=1.3)$ indicating a crystallization age of $2262 \pm 110 \mathrm{Ma}$ and positive $\varepsilon_{\mathrm{Nd}}(\mathrm{T})=+3.0$ (Figure 5).

$\mathrm{T}_{\mathrm{DM}}$ age of $2.25 \mathrm{Ga}$ and $\varepsilon_{\mathrm{Nd}}(\mathrm{T})$ of +3.15 of the felsic sample ANA 128 attest to the juvenile character of the magmatism (Table II, Figure 7).

\section{Jurubatuba Granite}

Zircon grains from ANA 5 are clear to yellowish and form stubby prismatic crystals. CL images (Figure 3B), show zircon crystals with typical magmatic growth zoning.

Fourteen spots of eleven zircons from ANA 

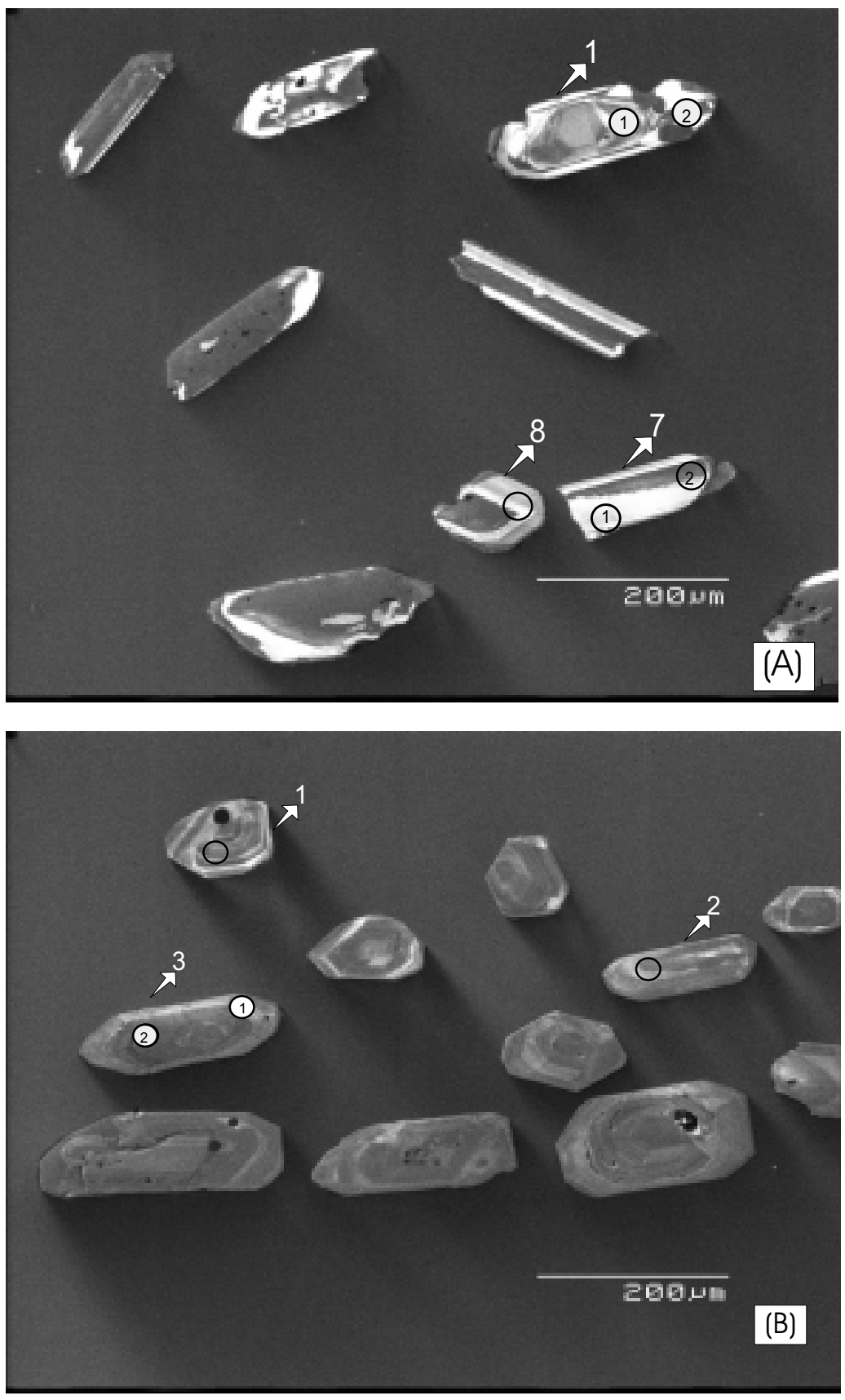

Fig. 3 - (A) CL images of zircon grains from felsic metavolcanic rock (sample ANA 128) of the Silvânia Sequence. (B) CL images of zircon from Jurubatuba Granite (sample ANA 5). Arrow indicates the zircon number and circle indicates analyzed spot. 


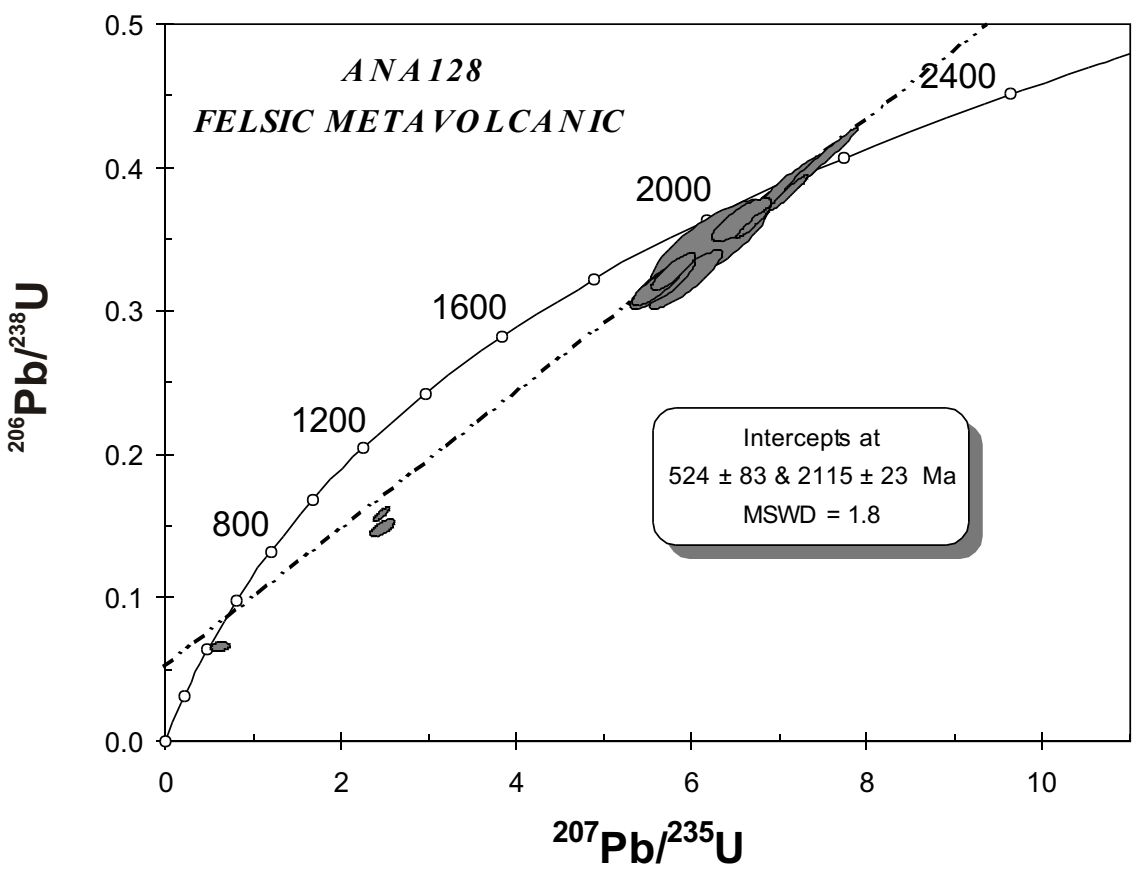

Fig. 4 - Concordia diagram of zircon analyses from Silvânia Sequence (ANA 128).

Data-point error ellipses are $68.3 \%$ conf.

5 were analysed (Table III). Twelve analyses are nearly concordant and yield an age of $2089 \pm 14$ Ma (Figure 6). Two analyses of rims (analyses 3.2 and 6.2, Table III) yielded younger and discordant ages suggesting $\mathrm{Pb}$ loss at ca. $574 \pm 75 \mathrm{Ma}$.

Sm-Nd whole rock analyses were performed on five samples of the Jurubatuba Granite (Table II, Figure 2). Samples ANA 5, 7a, 13, and 229 have Paleoproterozoic $\mathrm{T}_{\mathrm{DM}}$ model ages between 2.30 and $2.42 \mathrm{Ga}$. The oldest $\mathrm{T}_{\mathrm{DM}}$ value $(2.50 \mathrm{Ga})$ refers to a sedimentary xenolith in the granite (Sample 7b). $\varepsilon_{\mathrm{Nd}}(\mathrm{T})$ values vary between -0.22 and -0.58 . One sample of a diorite (ANA 229) has a $\mathrm{T}_{\mathrm{DM}}$ model age of $2.30 \mathrm{Ga}$ and $\varepsilon_{\mathrm{Nd}}(\mathrm{T})=+0.99$ (Figure 7).

\section{DISCUSSION}

$\mathrm{U}-\mathrm{Pb}$ and $\mathrm{Sm}-\mathrm{Nd}$ isotopic data indicate that the felsic volcanic rocks of the Silvânia Sequence and part of Jurubatuba Granite (ANA 229) are Paleoproterozoic and contain a large proportion of Paleoprotero- zoic juvenile crustal components. They are juvenile extracts from the mantle and represent a Paleoproterozoic crust forming event $\left(\varepsilon_{\mathrm{Nd}}=+3.0\right.$ and +0.99 respectively). $\mathrm{T}_{\mathrm{DM}}$ model age of ca. 2.25 $\mathrm{Ga}$ is equal within error to $\mathrm{U}-\mathrm{Pb}$ crystallization age of 2.11 Ga suggesting ca. 2.1-2.2 Ga crust forming event. Geochemical data (Oliveira 1994, Freitas and Kuyumjian 1995) indicate that protholiths were formed in an island arc setting (Lacerda Filho et al. 1991, Lacerda Filho and Oliveira 1995).

The difference between 2.3-2.4 Ga Jurubatuba granite model ages and $2.09 \mathrm{Ga}$ zircon crystallization age associated with slightly negative $\varepsilon_{\mathrm{Nd}}$ values at the time of crystallization indicate a limited but not negligible degree of crustal contamination as supported by common metasediment xenoliths, one of which displays the oldest model age $\left(\mathrm{T}_{\mathrm{DM}}=2.5\right.$ $\mathrm{Ga}$ ) so far recorded in the study area. This suggests that the granite is either derived from re-melting of Paleoproterozoic crustal rocks, including metasediments, or is heavily contaminated with them. 
TABLE I

Summary of SHRIMP U-Th-Pb zircon results for sample ANA 128.

\begin{tabular}{|c|c|c|c|c|c|c|c|c|c|c|c|c|c|c|c|c|c|c|c|}
\hline \multirow[b]{2}{*}{$\begin{array}{c}\text { Grain. } \\
\text { spot }\end{array}$} & \multirow[b]{2}{*}{$\begin{array}{c}\mathrm{U} \\
(\mathrm{ppm})\end{array}$} & & & \multirow[b]{2}{*}{$\begin{array}{l}\mathrm{Th} / \mathrm{U} \\
(\mathrm{ppm})\end{array}$} & \multirow[b]{2}{*}{$\begin{array}{l}{ }^{204} \mathrm{~Pb} / \\
{ }^{206} \mathrm{~Pb}\end{array}$} & \multirow[b]{2}{*}{$\begin{array}{c}\mathrm{f}_{206} \\
\%\end{array}$} & \multicolumn{6}{|c|}{ Radiogenic Ratios } & \multicolumn{6}{|c|}{$\operatorname{Ages}(\operatorname{in~Ma)}$} & \multirow[b]{2}{*}{$\begin{array}{c}\text { Conc } \\
\%\end{array}$} \\
\hline & & \multicolumn{2}{|c|}{$\begin{array}{c}\text { Th } \\
(\mathrm{ppm})\end{array}$} & & & & $\begin{array}{c}{ }^{206} \mathrm{~Pb} / \\
{ }^{238} \mathrm{U}\end{array}$ & \pm & $\begin{array}{c}{ }^{207} \mathrm{~Pb} / \\
{ }^{235} \mathrm{U}\end{array}$ & \pm & $\begin{array}{l}{ }^{207} \mathrm{~Pb} / \\
{ }^{206} \mathrm{~Pb}\end{array}$ & \pm & $\begin{array}{c}{ }^{206} \mathrm{~Pb} / \\
{ }^{238} \mathrm{U}\end{array}$ & \pm & $\begin{array}{c}{ }^{207} \mathrm{~Pb} / \\
{ }^{235} \mathrm{U}\end{array}$ & \pm & $\begin{array}{l}{ }^{207} \mathrm{~Pb} / \\
{ }^{206} \mathrm{~Pb}\end{array}$ & \pm & \\
\hline 1.1 & 186 & 65 & 0.3 & 76 & 0.000080 & 0.12 & 0.3876 & 0.0075 & 7.110 & 0.150 & 0.1331 & 0.0008 & 2,112 & 35 & 2,125 & 19 & 2,139 & 11 & 99 \\
\hline 1.2 & 640 & 109 & 0.2 & 116 & 0.000092 & 0.14 & 0.1764 & 0.0030 & 2.516 & 0.055 & 0.1034 & 0.0012 & 1,047 & 17 & 1,277 & 16 & 1,687 & 21 & 62 \\
\hline 2.1 & 323 & 22 & 0.1 & 118 & 0.000035 & 0.05 & 0.3682 & 0.0064 & 6.713 & 0.126 & 0.1322 & 0.0007 & 2,021 & 30 & 2,074 & 17 & 2,128 & 10 & 95 \\
\hline 3.1 & 149 & 110 & 0.7 & 28 & 0.000397 & 0.68 & 0.1671 & 0.0035 & 1.627 & 0.058 & 0.0706 & 0.0018 & 996 & 20 & 981 & 23 & 946 & 54 & 105 \\
\hline 3.2 & 330 & 53 & 0.2 & 27 & 0.001891 & 3.38 & 0.0870 & 0.0018 & 0.704 & 0.064 & 0.0587 & 0.0050 & 538 & 11 & 541 & 39 & 554 & 199 & 97 \\
\hline 4.1 & 46 & 13 & 0.3 & 16 & 0.000316 & 0.47 & 0.3305 & 0.0135 & 5.963 & 0.289 & 0.1309 & 0.0028 & 1,841 & 65 & 1,971 & 43 & 2,110 & 38 & 87 \\
\hline 5.1 & 191 & 77 & 0.4 & 84 & 0.000010 & 0.02 & 0.4095 & 0.0137 & 7.487 & 0.261 & 0.1326 & 0.0008 & 2,213 & 63 & 2,172 & 32 & 2,133 & 11 & 104 \\
\hline 2.2 & 28 & 5 & 0.2 & 10 & 0.001091 & 1.62 & 0.3548 & 0.0189 & 6.218 & 0.438 & 0.1271 & 0.0051 & 1,957 & 90 & 2,007 & 64 & 2,059 & 72 & 95 \\
\hline 6.1 & 149 & 33 & 0.2 & 60 & 0.000010 & 0.02 & 0.3926 & 0.0136 & 7.114 & 0.268 & 0.1314 & 0.0015 & 2,135 & 63 & 2,126 & 34 & 2,117 & 20 & 101 \\
\hline 7.1 & 77 & 14 & 0.2 & 26 & 0.000210 & 0.31 & 0.3355 & 0.0081 & 5.817 & 0.174 & 0.1258 & 0.0019 & 1,865 & 39 & 1,949 & 26 & 2,040 & 27 & 91 \\
\hline 7.2 & 140 & 121 & 0.9 & 25 & 0.000566 & 0.84 & 0.1666 & 0.0039 & 2.546 & 0.091 & 0.1108 & 0.0027 & 993 & 22 & 1,285 & 26 & 1,813 & 45 & 55 \\
\hline 8.1 & 204 & 29 & 0.1 & 67 & 0.000199 & 0.30 & 0.3257 & 0.0083 & 5.629 & 0.183 & 0.1254 & 0.0022 & 1,817 & 41 & 1,921 & 28 & 2,034 & 31 & 89 \\
\hline 9.1 & 46 & 16 & 0.3 & 18 & 0.000715 & 1.07 & 0.3702 & 0.0090 & 6.600 & 0.208 & 0.1293 & 0.0022 & 2,030 & 43 & 2,059 & 28 & 2,088 & 31 & 97 \\
\hline 10.1 & 27 & 6 & 0.24 & 9 & 0.000452 & 0.67 & 0.3277 & 0.0112 & 5.706 & 0.241 & 0.1263 & 0.0027 & 1,827 & 55 & 1,932 & 37 & 2,047 & 38 & 89 \\
\hline
\end{tabular}




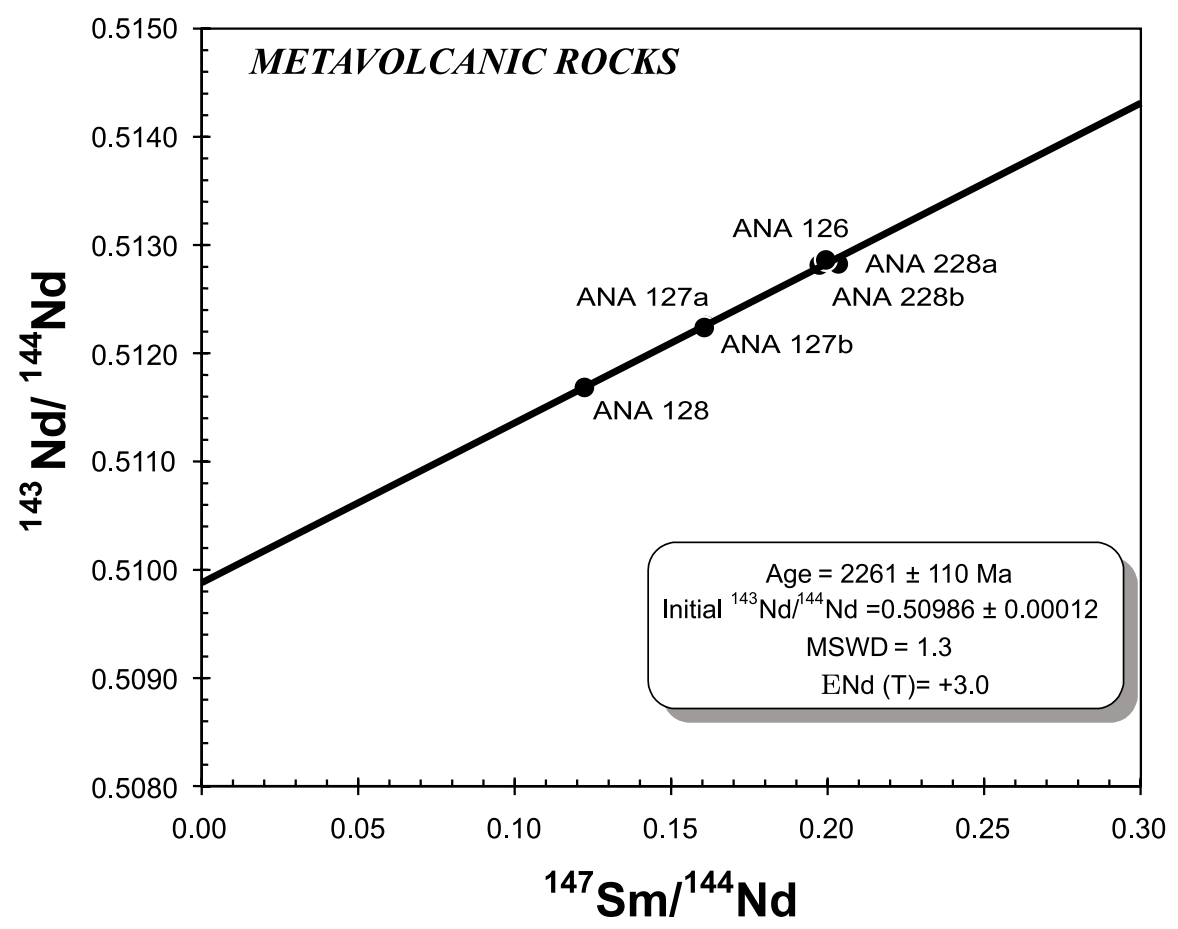

Fig. 5 - Sm-Nd whole-rock isochron of metavolcanic rocks from the Silvânia Sequence.

\section{TABLE II}

Sm-Nd isotopic data for rocks from the Silvânia Sequence and Jurubatuba Granite.

\begin{tabular}{|c|c|c|c|c|c|c|c|}
\hline \multicolumn{8}{|c|}{ Silvânia Sequence } \\
\hline Sample & $\mathrm{Sm}(\mathrm{ppm})$ & $\mathrm{Nd}(\mathrm{ppm})$ & ${ }^{147} \mathrm{Sm} /{ }^{144} \mathrm{Nd}$ & ${ }^{143} \mathrm{Nd} /{ }^{144} \mathrm{Nd}^{*}$ & $\mathrm{~T}_{\mathrm{DM}}(\mathrm{Ga})$ & $\varepsilon_{\mathrm{Nd}}(0)$ & $\varepsilon_{\mathrm{Nd}}(2115)$ \\
\hline Ana 126 & 2.89 & 8.593 & 0.203326 & $0.512848(22)$ & \multirow{6}{*}{2.25} & \multirow{6}{*}{-18.57} & \multirow{6}{*}{+3.15} \\
\hline Ana 127 & 3.003 & 11.278 & 0.160939 & $0.512259(11)$ & & & \\
\hline Ana 127(b) & 2.779 & 10.467 & 0.16049 & $0.512239(25)$ & & & \\
\hline Ana 128 & 1.871 & 9.251 & 0.122254 & $0.511686(43)$ & & & \\
\hline Ana 228(a) & 2.346 & 7.190 & 0.197242 & $0.512817(27)$ & & & \\
\hline Ana 228(b) & 2.805 & 8.0503 & 0.199399 & $0.512865(28)$ & & & \\
\hline \multicolumn{8}{|c|}{ Jurubatuba Granite } \\
\hline Sample & Sm (ppm) & $\mathrm{Nd}(\mathrm{ppm})$ & ${ }^{147} \mathrm{Sm} /{ }^{144} \mathrm{Nd}$ & ${ }^{143} \mathrm{Nd} /{ }^{144} \mathrm{Nd}^{*}$ & $\mathrm{~T}_{\mathrm{DM}}(\mathrm{Ga})$ & $\varepsilon_{\mathrm{Nd}}(0)$ & $\varepsilon_{\mathrm{Nd}}(2089)$ \\
\hline Ana 5 & 10.005 & 65.89 & 0.0922 & $0.511175(29)$ & 2.333 & -28.54 & -0.53 \\
\hline Ana 7(a) & 6.784 & 36.342 & 0.1128 & $0.511471(19)$ & 2.367 & -22.76 & -0.28 \\
\hline Ana 13 & 6.116 & 28.477 & 0.1298 & $0.511708(16)$ & 2.417 & -18.13 & -0.22 \\
\hline Ana 229 & 9.0516 & 42.671 & 0.12890 & $0.511756(18)$ & 2.30 & -17.21 & +0.99 \\
\hline $\begin{array}{l}\text { Ana 7(b) } \\
\text { (xenolith) }\end{array}$ & 6.544 & 32.139 & 0.1231 & $0.511555(09)$ & 2.506 & -21.13 & \\
\hline
\end{tabular}

${ }^{*}$ The numbers in parenteses are $1 \sigma$ errors in the last two digits of the isotopic ratio. 


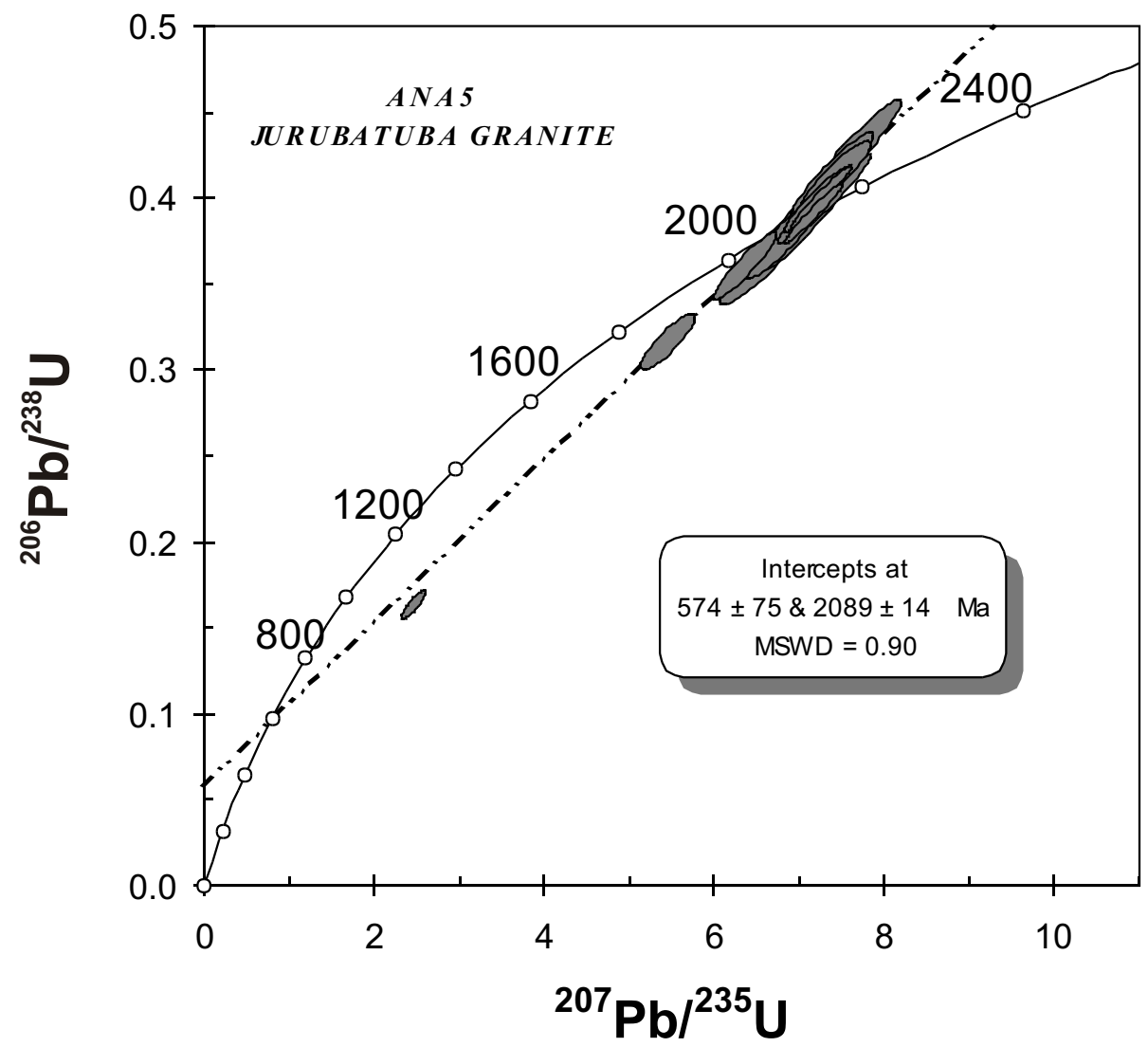

Fig. 6 - Concordia diagram for the Jurubatuba granite (sample ANA 5). Data-point error ellipses are $68.3 \%$ conf.

Paleoproterozoic rocks have been described previously in other areas of the Tocantins Province. Granite gneiss to the south and east of the Barro Alto mafic-ultramafic layered complex has been dated at $2128 \pm 15 \mathrm{Ma}\left({ }^{207} \mathrm{~Pb} /{ }^{206} \mathrm{~Pb}\right)($ Correia et al. 1997). Calc-alkaline granite gneiss from the Almas-Dianópolis area has been dated at ca. 2.2 Ga (U-Pb SHRIMP on zircon, Cruz et al. 2000). The latter is probably the western extension of Paleoproterozoic rocks which underlie the San Francisco Craton to the east of the Brasilia Belt.

Zircons of both lithological units also present $\mathrm{Pb}$ loss at $524 \pm 83 \mathrm{Ma}$ and $574 \pm 75 \mathrm{Ma}$, related to the Brasiliano/Pan-African metamorphic event. This event is evident in different parts of the Brasília Belt: in the Goiás Massif, Queiroz et al. (1999) re- port ages of $590 \pm 10 \mathrm{Ma}$ (U-Pb SHRIMP in zircon and titanite); Fortes and Jost (1996) dated the metamorphic peak in Crixás Greenstone Belt at ca. 550 $\mathrm{Ma}$ (Ar-Ar and K-Ar in muscovite); K-Ar in muscovite and biotite in samples from Araxá Group and Anápolis-Itauçu Complex near Goiânia yielded ages between $580 \mathrm{Ma}$ and $800 \mathrm{Ma}$ (Hasui and Almeida 1970).

\section{CONCLUSIONS}

The Paleoproterozoic crystallization ages (U-Pb SHRIMP and Sm-Nd whole rock isochron) of the volcano-sedimentary Silvânia Sequence and of the Jurubatuba Granite are the first documented evidence of a ca. 2.14-2.08 Ga juvenile magmatic event in the basement of the southern portion of the 
TABLE III

Summary of SHRIMP U-Th-Pb zircon results for sample ANA 5.

\begin{tabular}{|c|c|c|c|c|c|c|c|c|c|c|c|c|c|c|c|c|c|c|c|}
\hline \multirow[b]{2}{*}{$\begin{array}{c}\text { Grain. } \\
\text { spot }\end{array}$} & \multirow[b]{2}{*}{$\begin{array}{c}\mathrm{U} \\
(\mathrm{ppm})\end{array}$} & \multirow{2}{*}{\multicolumn{2}{|c|}{$\begin{array}{c}\text { Th } \\
(\mathrm{ppm})\end{array}$}} & \multirow[b]{2}{*}{$\begin{array}{l}\mathrm{Th} / \mathrm{U} \\
(\mathrm{ppm})\end{array}$} & \multirow[b]{2}{*}{$\begin{array}{l}{ }^{204} \mathrm{~Pb} / \\
{ }^{206} \mathrm{~Pb}\end{array}$} & \multirow[b]{2}{*}{$\begin{array}{c}\mathrm{f}_{206} \\
\%\end{array}$} & \multicolumn{6}{|c|}{ Radiogenic Ratios } & \multicolumn{6}{|c|}{ Ages $\quad($ in $M a)$} & \multirow[b]{2}{*}{$\begin{array}{c}\text { Conc. } \\
\%\end{array}$} \\
\hline & & & & & & & $\begin{array}{c}{ }^{206} \mathrm{~Pb} / \\
238 \mathrm{U}\end{array}$ & \pm & $\begin{array}{c}{ }^{207} \mathrm{~Pb} / \\
{ }^{235} \mathrm{U}\end{array}$ & \pm & $\begin{array}{l}{ }^{207} \mathrm{~Pb} / \\
{ }^{206} \mathrm{~Pb}\end{array}$ & \pm & $\begin{array}{c}{ }^{206} \mathrm{~Pb} / \\
{ }^{238} \mathrm{U}\end{array}$ & \pm & $\begin{array}{c}{ }^{207} \mathrm{~Pb} / \\
{ }^{235} \mathrm{U}\end{array}$ & \pm & $\begin{array}{l}{ }^{207} \mathrm{~Pb} / \\
{ }^{206} \mathrm{~Pb}\end{array}$ & \pm & \\
\hline 1.1 & 174 & 83 & 0.48 & 76 & 0.000015 & 0.02 & 0.4027 & 0.0123 & 7.205 & 0.238 & 0.1298 & 0.0012 & 2.182 & 57 & 2.137 & 30 & 2.095 & 17 & 104 \\
\hline 2.1 & 113 & 54 & 0.48 & 49 & 0.000010 & 0.02 & 0.3974 & 0.0128 & 7.142 & 0.253 & 0.1304 & 0.0015 & 2.157 & 59 & 2.129 & 32 & 2.103 & 20 & 103 \\
\hline 3.1 & 190 & 53 & 0.28 & 73 & 0.000181 & 0.27 & 0.3651 & 0.0124 & 6.381 & 0.240 & 0.1268 & 0.0016 & 2.006 & 59 & 2.030 & 34 & 2.053 & 22 & 98 \\
\hline 3.2 & 702 & 154 & 0.22 & 126 & 0.000299 & 0.45 & 0.1762 & 0.0051 & 2.511 & 0.087 & 0.1033 & 0.0016 & 1.046 & 28 & 1.275 & 25 & 1.685 & 29 & 62 \\
\hline 4.1 & 40 & 14 & 0.34 & 18 & 0.000034 & 0.05 & 0.4312 & 0.0184 & 7.666 & 0.358 & 0.1289 & 0.0019 & 2.311 & 83 & 2.193 & 43 & 2.084 & 26 & 111 \\
\hline 4.2 & 202 & 93 & 0.46 & 88 & 0.000010 & 0.02 & 0.4043 & 0.0120 & 7.270 & 0.226 & 0.1304 & 0.0009 & 2.189 & 55 & 2.145 & 28 & 2.104 & 11 & 104 \\
\hline 5.1 & 263 & 125 & 0.48 & 113 & 0.000010 & 0.02 & 0.3951 & 0.0117 & 7.181 & 0.225 & 0.1318 & 0.0009 & 2.146 & 54 & 2.134 & 28 & 2.123 & 12 & 101 \\
\hline 6.1 & 73 & 36 & 0.49 & 33 & 0.000182 & 0.27 & 0.4171 & 0.0158 & 7.389 & 0.315 & 0.1285 & 0.0019 & 2.247 & 72 & 2.160 & 39 & 2.078 & 27 & 108 \\
\hline 6.2 & 249 & 136 & 0.55 & 89 & 0.000272 & 0.41 & 0.3228 & 0.0100 & 5.465 & 0.206 & 0.1228 & 0.0022 & 1.803 & 49 & 1.895 & 33 & 1.998 & 32 & 90 \\
\hline 7.1 & 49 & 26 & 0.53 & 21 & 0.000109 & 0.16 & 0.3891 & 0.0174 & 6.995 & 0.360 & 0.1304 & 0.0026 & 2.119 & 81 & 2.111 & 47 & 2.103 & 36 & 101 \\
\hline 8.1 & 73 & 35 & 0.49 & 30 & 0.000010 & 0.02 & 0.3728 & 0.0187 & 6.648 & 0.377 & 0.1293 & 0.0027 & 2.043 & 89 & 2.066 & 51 & 2.089 & 37 & 98 \\
\hline 9.1 & 109 & 86 & 0.79 & 52 & 0.000053 & 0.08 & 0.4165 & 0.0125 & 7.441 & 0.260 & 0.1296 & 0.0019 & 2.245 & 57 & 2.166 & 32 & 2.092 & 26 & 107 \\
\hline 10.1 & 21 & 8 & 0.38 & 9 & 0.000010 & 0.02 & 0.3804 & 0.0139 & 6.793 & 0.291 & 0.1295 & 0.0024 & 2.078 & 65 & 2.085 & 39 & 2.092 & 32 & 99 \\
\hline 11.1 & 44 & 30 & 0.68 & 21 & 0.000010 & 0.02 & 0.4078 & 0.0134 & 7.448 & 0.262 & 0.1325 & 0.0012 & 2.205 & 62 & 2.167 & 32 & 2.131 & 16 & 104 \\
\hline
\end{tabular}




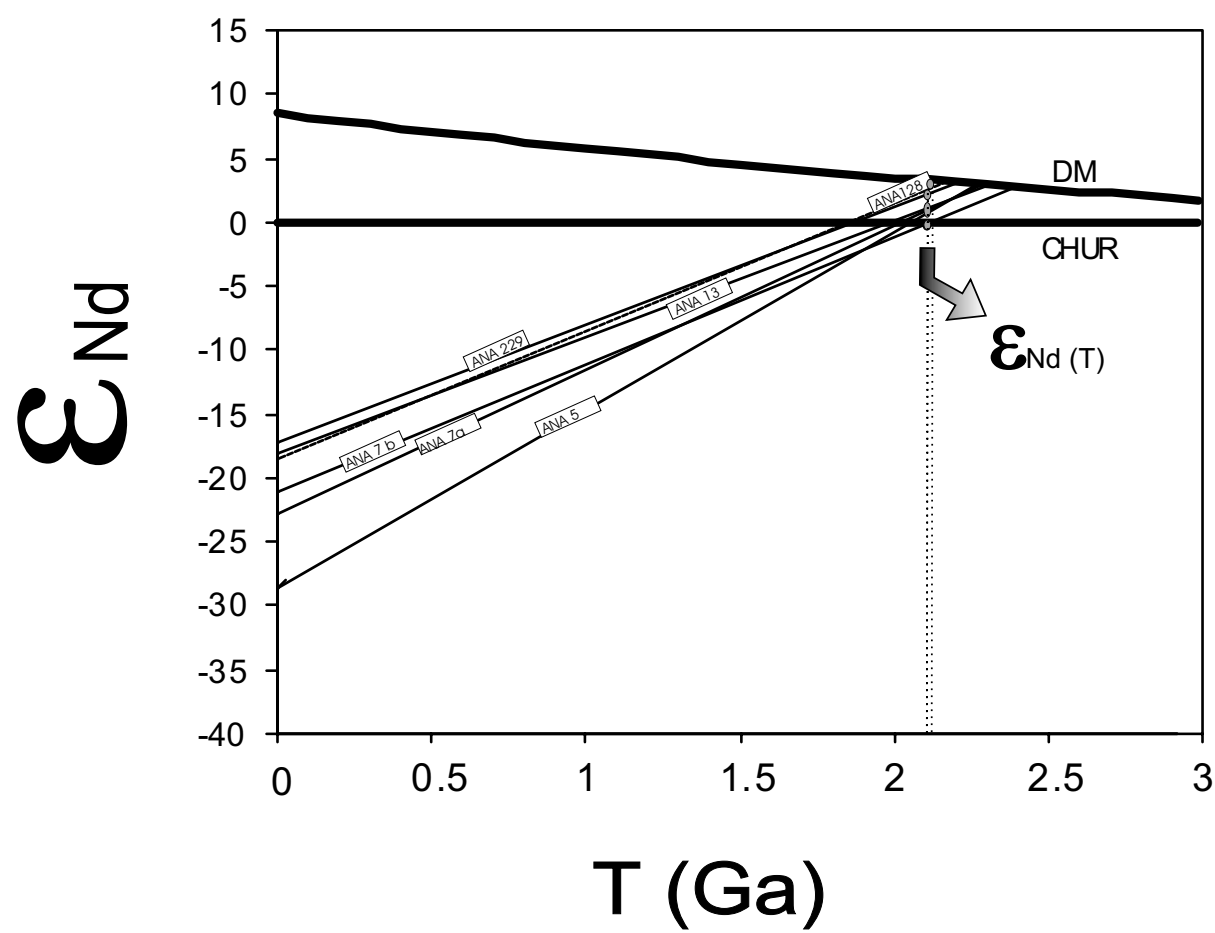

Fig. 7 - Nd isotopic evolution diagram for samples of Jurubatuba granite and felsic volcanics from the Silvânia Sequence.

Brasilia Belt. U-Pb SHRIMP zircon ages of the Silvânia dacite and Jurubatuba granite are similar: $2115 \pm 23 \mathrm{Ma}$ and $2089 \pm 14$ Ma respectively and rim overgrown in zircon of both lithological units indicate recrystallization during the Brasiliano/PanAfrican metamorphic event.

Isotopic, litogeochemical, and field data suggest a Paleoproterozoic magmatic arc setting which we named Silvânia Magmatic Arc with juvenile magma as indicated by positive $\varepsilon_{\mathrm{Nd}}$ at the time of crystallization. The homogeneous and slightly negative $\mathrm{Sm}-\mathrm{Nd}$ model ages and $\varepsilon_{\mathrm{Nd}}$ values at the time of crystallization of the Jurubatuba Granite suggest crustal contamination. The oldest $\mathrm{T}_{\mathrm{DM}}(2.5 \mathrm{Ga})$ in the study area is from a xenolith within the granite body. These data suggest that the original granitic magma was derived by the remelting of crustal rocks, including sedimentary sources similar to the enclave or was heavily contaminated by it.

The Silvânia Magmatic Arc probably rep- resents the westernmost autochthonous exposure of Paleoproterozoic rocks belonging to the São Francisco continent involved in the Neoproterozoic orogeny. During the Neoproterozoic the Silvânia Magmatic Arc was juxtaposed with the AnápolisItauçu Complex and Araxá Group.

\section{ACKNOWLEDGEMENTS}

This work was supported by grants from $\mathrm{CNPq}$ (Proc. 52.2269/95-8, 42.0081/99-2) and FAP-DF (193.000.068/96) to RAF. We thank Simone Gioia and Sérgio Junges for assistance in the Laboratory of Geochronology of University of Brasília. We also thank two anonymous referees for reviewing the manuscript.

\section{RESUMO}

Idades isótopicas U-Pb SHRIMP e Sm-Nd foram determinadas em rochas metavulcânicas félsicas da Sequiên- 
cia de Silvânia e Granito Jurubatuba na porção central da Faixa Brasília. Grãos de zircão da rocha metavulcânica da Seqüência de Silvânia e do granito forneceram, respectivamente, as idades de $2115 \pm 23$ Ma e $2089 \pm$ $14 \mathrm{Ma}$, interpretadas como idades de cristalização destas rochas. Amostras da Seqüência de Silvânia resultaram em isócrona $\mathrm{Sm}-\mathrm{Nd}$ em rocha total, indicando idade de cristalização de $2262 \pm 110 \mathrm{Ma}$ e $\varepsilon_{\mathrm{Nd}}(\mathrm{T})=+3.0$ interpretada como representativa de evento magmático juvenil para estas rochas.

Análises isótopicas de $\mathrm{Nd}$ em amostras do Granito Jurubatuba resultaram em idades modelo $\mathrm{T}_{\mathrm{DM}}$ entre $2.30 \mathrm{e}$ $2.42 \mathrm{Ga}$ e valores de $\varepsilon_{\mathrm{Nd}}(\mathrm{T})$ variando entre $-0.22 \mathrm{e}-0.58$. $\mathrm{O}$ valor mais antigo de idade modelo $\mathrm{T}_{\mathrm{DM}}$ refere-se a xenólito de rocha metassedimentar no granito. As idades de cristalização paleoproterozóicas da Sequiência de Silvânia e do Granito Jurubatuba são a primeira evidência de evento magmático juvenil ocorrido entre 2.14-2.08 Ga no embasamento da porção central da Faixa Brasília.

Palavras-chave: U-Pb SHRIMP, dados isotópicos SmNd, Faixa Brasília, embasamento.

\section{REFERENCES}

Almeida FFM, Hasui Y, Neves BBB and Fuck RA 1981. Brazilian structural provinces: an introduction. Earth Sci Review 17: 1-29.

Araújo VA. 1994. Programa de levantamentos geológicos básicos do Brasil. Folha SE.22-X-B-I - Nerópolis. Estado de Goiás. Escala 1:100.000. Goiânia: DNPM/CPRM, 120p.

Correia CT, Tassinari CCG, Lambert DD, Kinny PD AND GIRARDI VAV. 1997. U-Pb (SHRIMP), Sm-Nd and Re-Os systematics of the Cana Brava, Niquelândia and Barro Alto layered intrusions in central Brazil, and constraints on the tectonic evolution. In: SouTH American Symposium on Isotope Geology, 1, Campos do Jordão. Actas..., Campos do Jordão. 1999, p. 88-89.

Cruz ElCC, Hagemann SG, McNaughton N, KuyumJian RM. 2000. Paleoproterozoic U-Pb SHRIMP ages of low and high-Al low-K calc-alkaline granitoids in the Brasília Fold Belt basement. In: International Geological Congress, 31, Rio de
Janeiro. Abstracts Volume, CD, Rio de Janeiro, 2000.

Danni JCM, Fuck RA ANd Leonardos JR OH. 1982. Archean and Lower Proterozoic Units in Central Brazil. Geol Rundschau 71: 291-317.

Dardenne MA. 2000. The Brasília Fold Belt. In: CoRDANI UG ET AL. (Ed); Tectonic Evolution of South America. Rio de Janeiro: $31^{\text {st }}$ IGC, p. 231-263.

DePaolo DJ. 1981. A neodymium and strontium isotopic study of the Mesozoic calc-alkaline granitic batholiths of the Sierra Nevada and Peninsular Ranges, California. J Geophys Res 86: 1047010488 .

Drake Jr AA. 1980. The Serra de Caldas Window, Goiás. USGS Prof. Paper. 1119A-B: 1-11.

Fischel DP, Pimentel MM and Fuck RA. 1998. Idade de metamorfismo de alto grau no Complexo Anápolis-Itauçu, determinada pelo método Sm-Nd. Rev Bras Geoc 28(4): 543-544.

Fischel DP, Pimentel MM and Fuck RA. 1999. Preliminary Sm-Nd isotopic study of the AnápolisItauçu Complex, Araxá Group, and associated granite intrusions, central Brazil: implications for the evolution of the Brasília Belt. In: South American Symposium on Isotope Geology, 2, Córdoba. Actas..., Córdoba, 1999. p. 302-305.

Fortes PTFO AND Jost H. 1996. Metallogeny of Mina III, Mina Nova and Mina Inglesa gold deposits, Crixás Greenstone Belt, central Brazil. Symposium Archaean Terranes of the South American Plataform, Extend Abstracts..., Brasília, 1996. p. 18-19.

Freitas ME and Kuyumjian RM. 1995. Variação química das micas durante o hidrotermalismo peraluminoso de Vianópolis, GO. B Geoc Centro Oeste 18(1/2): 44-56.

Fuck RA, Jardim de Sá EF, Pimentel MM, Dardenne MA AND SoARes ACP. 1993. As faixas de dobramentos marginais do Cráton do São Francisco: síntese dos conhecimentos. In: Dominguez JML AND Misi A. (Eds.), O Cráton de São Francisco. Salvador: SBG-SGM-CNPq, p. 161-185.

Fuck RA, Pimentel MM and D’el Rey Silva LJH. 1994. Compartimentação tectônica da porção orien- 
tal da Província Tocantins. In: Congresso BrasiLeiro de Geologia, 38, Balneário Camboriú. Actas..., Florianópolis, SBG, 1994. p. 215-216.

Gioia SMCL and Pimentel MM. 2000. The Sm-Nd isotopic method in the Geochronology Laboratory of the University of Brasília. An Acad Bras Ci 72(2): 219-245.

Hasui Y And Almeida FFM. 1970. Geocronologia do Centro-Oeste brasileiro. Bol Soc Bras Geol 19(1): $5-26$.

Lacerda Filho JV and Oliveira CC. 1995. Geologia da região centro-sul de Goiás. Bol Geoc CentroOeste 18(1/2): 3-19.

Lacerda Filho JV, Marques V, Scislewiski G, Jorge L, Justo EC And Oliveira CC. 1991. Programa de levantamentos geológicos básicos do Brasil. Folha SE.22-X-B-VI - Caraíba. Estado de Goiás. Escala 1:100.000. Goiânia, DNPM/CPRM, 145p.

LuDWIG KR. 1999. User's Manual for Isoplot/Ex version 2.05. Berkeley Geochronology Center, Special Publication $\mathrm{N}^{\circ}$ 1a. Berkeley, CA. 48p.

Marini OJ, Fuck RA, Danni JCM, Dardenne MA, Loguercio SOC AND Ramalho R. 1984. As faixas de dobramentos Brasília, Uruaçu e ParaguaiAraguaia e o Maciço Mediano de Goiás. In: ScHobBenhaus C ET AL. (Ed); Geologia do Brasil. Brasília: MME-DNPM, p. 251-303.

Oliveira CC. 1994. Programa de levantamentos geológicos básicos do Brasil. Folha SE.22-X-B-V Leopoldo de Bulhões. Estado de Goiás. Escala 1:100.000. Goiânia, DNPM/CPRM, 172p.

Pimentel MM and Fuck RA. 1992. Neoproterozoic crustal accretion in central Brazil. Geology 20: 375379.

Pimentel MM, Heaman L and Fuck RA. 1991. U-Pb zircon and sphene geochronology of late Proterozoic volcanic arc rock units from southwestern Goiás, central Brazil. Journal of South American Earth Sciences 4: 329-339.

Pimentel MM, Whitehouse MJ, Viana MG, Fuck RA and Machado N. 1997. The Mara Rosa arc in the Tocantins Province: further evidence for Neoprotero- zoic crustal accretion in central Brazil. Precambrian Res 81: 229-310.

Pimentel MM, Fuck RA AND Fischel DP. 1999a. Estudo isotópico $\mathrm{Sm}-\mathrm{Nd}$ regional da porção central da Faixa Brasília: implicações para idade e origem dos granulitos do Complexo Anápolis-Itauçu e sedimentos do Grupo Araxá. Rev Bras Geoci 29(2): 271-276.

Pimentel MM, Dardenne MA, Viana MG, Gioia SMCL, Junges S ANd SeER H. 1999b. Nd isotopes and the provenance of sediments of the Neoproterozoic Brasília Belt, central Brazil: Geodynamic implications. In: South American Symposium on Isotope Geology, 2, Córdoba. Actas..., Córdoba, 1999. p. $426-429$.

Pimentel MM, Fuck RA and Botelho NF. 2000a. Granites and the geodynamic history of the Brasília Belt, central Brazil: a review. Lithos 46: 463-483.

Pimentel MM, Fuck RA, Jost H, Ferreira Filho CF and Araújo SM. 2000b. The basement of the Brasília Fold Belt and the Goiás Magmatic Arc. In: Cordani UG ET AL. (Eds); Tectonic Evolution of South America. Rio de Janeiro: 31 ${ }^{\text {st }}$ IGC, 2000, p. 190-229.

Queiroz CL, McNaughton N And Jost H. 1999. Formation of a dome-and-keel province: $150 \mathrm{Ma}$ of granitoid magmatism in the Crixás Granite-Greenstone Belt Terrain. In: Simpósio DE GEOLOGIA DO Centro-Oeste e Simpósio de Geologia de Minas Gerais, 7, Brasília. Bol. Resumos..., Brasília, SBG, 1999. p. 71.

SATO K. 1998. Evolução crustal da Plataforma SulAmericana, com base na geoquímica isotópica SmNd. Unpublished PhD Thesis, Univ. São Paulo, 299p.

Stern RA. 1997. The GSC Sensitive High Resolution Ion Microprobe (SHRIMP): analytical techniquesof zircon $\mathrm{U}-\mathrm{Th}-\mathrm{Pb}$ age determinations and performance evaluation. In: RADIOGENIC AGE AND IsotopiC StUdies: REPORT IO; Geological Survey of Canada, Current Research 1997-F, p. 1-31.

Strieder AJ ANd Nilson AA. 1992. Mélange ofiolítica nos metassedimentos do Grupo Araxá de Abadiânia (GO) e implicações tectônicas regionais. Rev Bras 
Geoc 22: 204-215.

Tassinari CCG, Cordani UG, Correia CT, Nutman A, Kinny P, Marins C and Dias Neto CM. 1999.

Dating of granulites by SHRIMP U-Pb systematics in Brazil: constraints for the age of the metamorphism of Proterozoic orogenies. In: South AmeriCan Symposium on Isotope Geology, 2, Córdoba. Actas..., Córdoba, 1999. p. 371-373.

Valente CR. 1986. Projeto Mapas Metalogenéticos e de previsão de Recursos Minerais. Folha Goiânia, SE.22-X-D. Brasília, DNPM/CPRM.
Williams IS AND Meyer C. 1998. U-Pb geochronology of zircons from lunar breccia 73217 using a sensitive high mass-resolution ion microprobe. J. Geophys. Res. 89: B525-B534.

Winge M. 1995. Evolução dos terrenos granulíticos da Província Estrutural Tocantins, Brasil central. Unpublished Ph.D. thesis, Univ. de Brasília, Brasília, 600 p.

WolfF F. 1991. Caracterização petrográfica, litogeoquímica, química mineral e geotermometria de rochas de alto grau metamórfico do Complexo Anápolis-Itauçu, Goiás. Unpublished M.Sc. thesis, Univ. Fed. Rio de Janeiro, Rio de Janeiro, 148p. 